\title{
Konsk, mein shtetele Konsk (1939)
}

\author{
Hadasa Cytrynowicz*
}

A terra tremeu, Konsk tremeu, as ruelas, as casinhas, o pássaro na gaiola, a máquina de costura da minha mãe, as panelas da avó, as janelas... Nós trememos. O meu coração parou de bater e, logo em seguida, disparou como nunca.

Konsk foi coberta por uma praga. Praga preta, terrível. Voltaram os dias das pragas do Egito. Eram as motocicletas voadoras do Terceiro Reich, reluzentes, de olhos enormes, brilhantes e amarelos, pisando tudo o que encontravam, fazendo o mundo tremer e o meu coração bater como o passarinho que se debatia na gaiola. O meu pobre canarinho amarelinho. Os dois queriam voar, fugir.

As motocicletas pretas voadoras de olhos reluzentes carregavam figuras pretas de couro brilhante, de óculos magníficos, de quepes pretos, de botas de cano alto, que não acabavam nunca... não acabavam nunca. Konsk foi coberta por uma praga preta, Konsk, mein shtetele Konsk tremeu nos seus alicerces. E fez-se um silêncio pesado, perturbador, paramos de respirar. E agora? Fogo! Gritos cortaram o silêncio. Fogo! Fogo!

Judeus, onde tem fogo? Onde tem fogo? Começou a confusão da Torre de Babel. Ninguém se entendia, fogo? Onde? Lá! Aqui! Fogo! Judeus-Judeeeeeeus!

Judeus corriam com baldes e barris de água. Papai correu para ajudar. Minha mãe me apertava tanto ao seu coração, tão forte que eu quase não conseguia respirar. A antiga sinagoga de madeira de Konsk estava em chamas. A nossa sinagoga. Lá dentro, trancada, a Sagrada Torá, os Livros Sagrados de mil anos, a Arca Sagrada, o púlpito, os bancos entalhados com carinho e amor por um artesão famoso ardiam com um fogo terrível, satânico. Fogo dos que vieram com as motocicletas voadoras, os incendiários! Ouviam-se gritos dos piedosos e da gente comum: Shmá Israel...!

Não havia água suficiente, os bombeiros poloneses não apareceram. Fez-se um silêncio, um silêncio enorme. Nada. Tóhu vavóhu.

Minha mãe me apertava nos braços. Ainda sinto os teus braços, mãe (mãe tão pequena de Konsk), vou sempre senti-los, vou sentir a força que você me transmitiu, mãe pequena,mas tão forte. Konsk, mein shtetele Konsk.

\footnotetext{
* Hadasa Cytrynowicz é professora, tradutora e escritora.
} 